\title{
Incident Scenarios Collection for Public Safety Communications Research Framing the Context of Use
}

\author{
Yee-Yin Choong \\ Shaneé Dawkins \\ Kristen Greene \\ Mary Theofanos
}




\title{
Incident Scenarios Collection for Public Safety Communications Research Framing the Context of Use
}

\author{
Yee-Yin Choong \\ Shaneé Dawkins \\ Kristen Greene \\ Information Access Division \\ Information Technology Laboratory \\ Mary Theofanos \\ Office of Data and Informatics \\ Material Measurement Laboratory
}

This publication is available free of charge from: https://doi.org/10.6028/NIST.IR.8181

June 2017

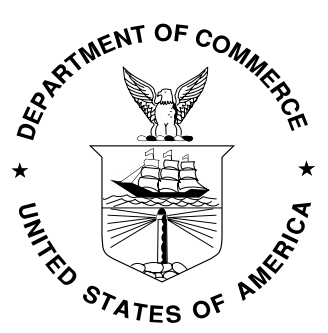

U.S. Department of Commerce Wilbur L. Ross, Jr., Secretary 


\section{Incident Scenarios ( Collection for Public Safety Communications Research ( Framing the Context of Use}

VERSION: 1.0

JUNE 2017 


\title{
Contacts:
}

This document was developed by the Public Safety Communications Research (PSCR) Usability Team at the National Institute of Standards and Technology (NIST).

National Institute of Standards and Technology

Communications Technology Laboratory

Gaithersburg, MD 20899

\author{
Yee-Yin Choong \\ Industrial Psychologist \\ 301.975.3248 \\ yee-yin.choong@nist.gov \\ Shaneé Dawkins \\ Computer Scientist \\ 301.975.4464 \\ shanee.dawkins@nist.gov \\ Kristen Greene \\ Cognitive Scientist \\ 301.975.8119 \\ kristen.greene@nist.gov \\ Mary Theofanos \\ Computer Scientist \\ 301.975.5889 \\ maryt@nist.gov
}




\section{Table of Contents}

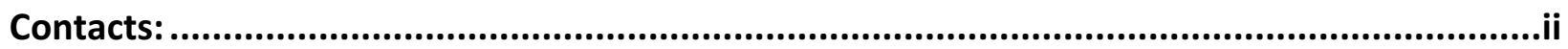

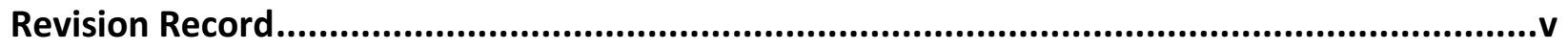

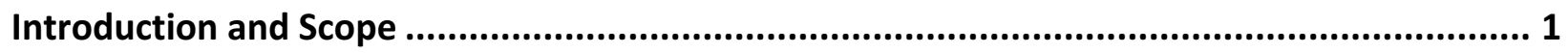

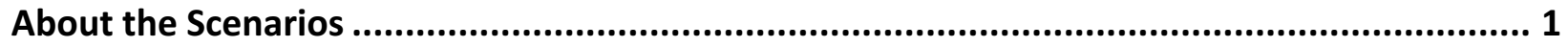

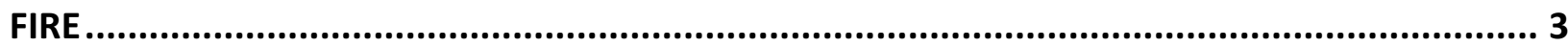

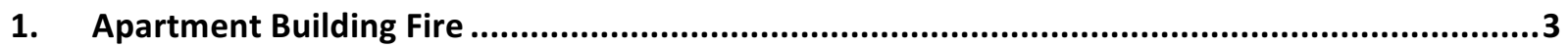

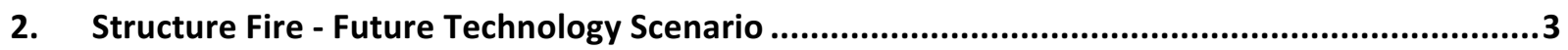

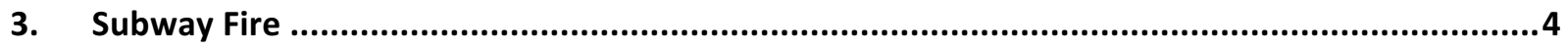

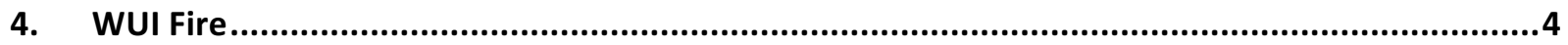

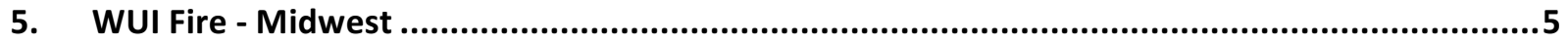

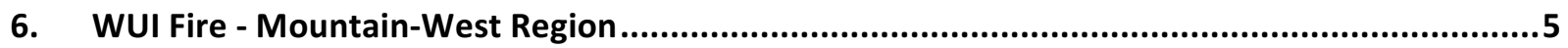

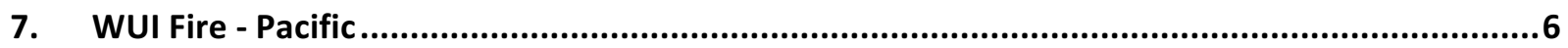

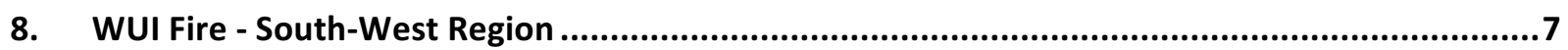

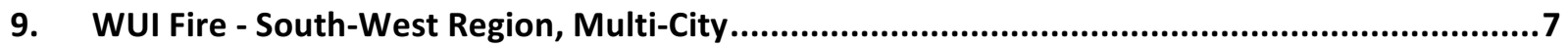

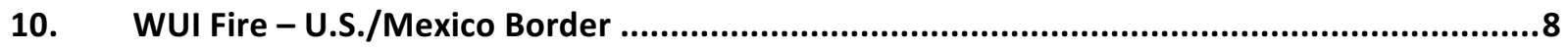

Law Enforcement ............................................................................................................ 9

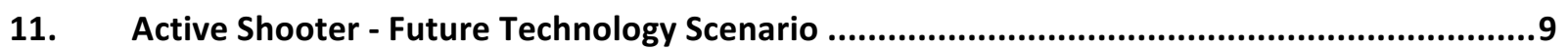

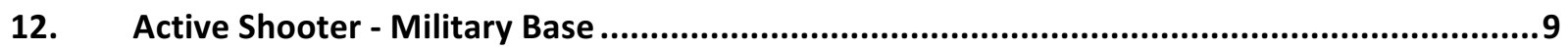

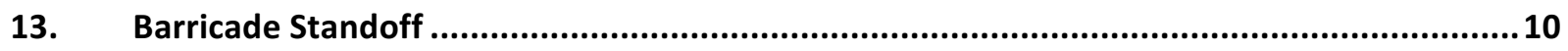

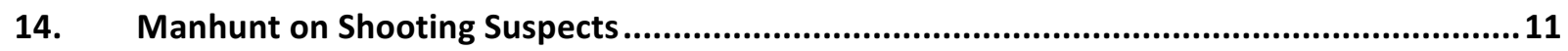

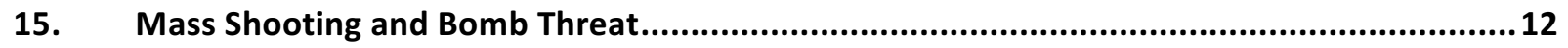

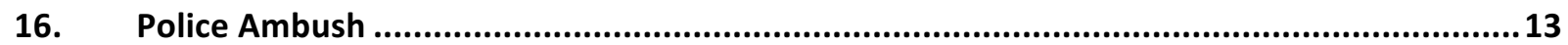

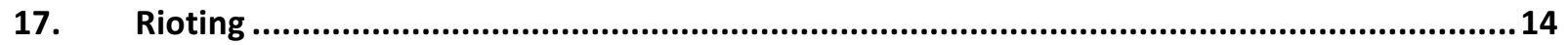

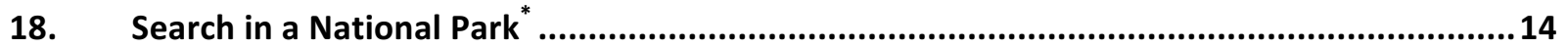

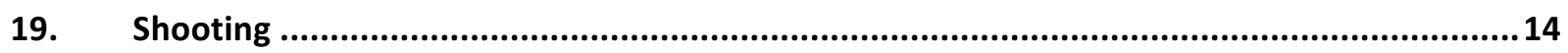

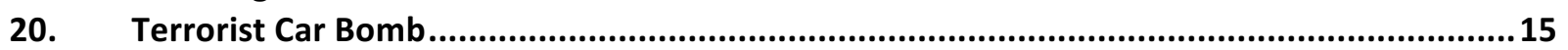

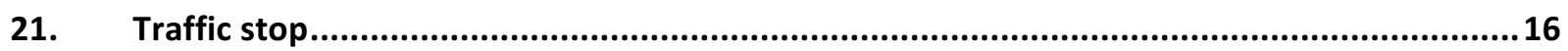

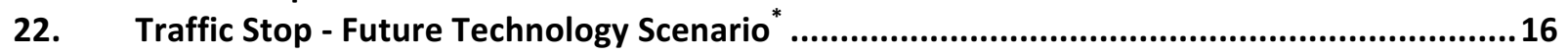

23. Undercover Officer - Future Technology Scenario ........................................................17

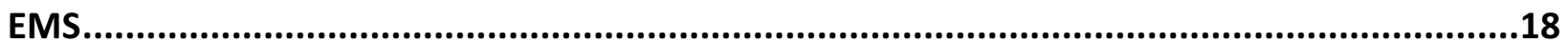

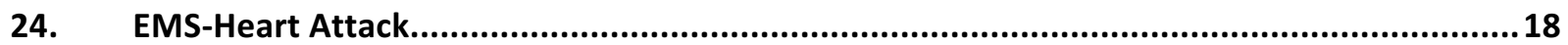

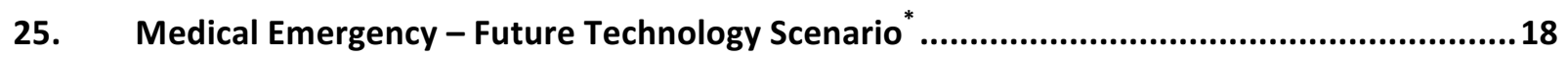

26. Routine Patient Services and Car Crash Scenario - Future Technology Scenario ..................19

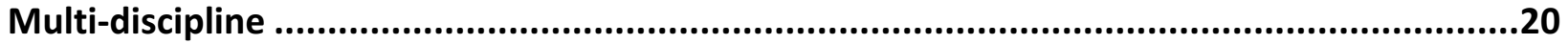

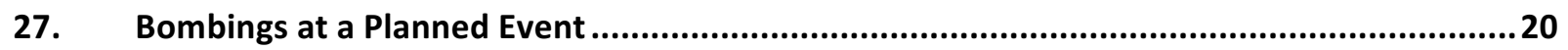

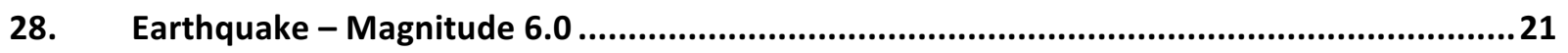

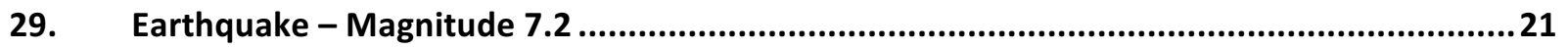

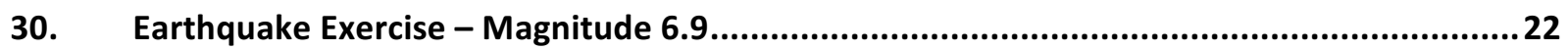

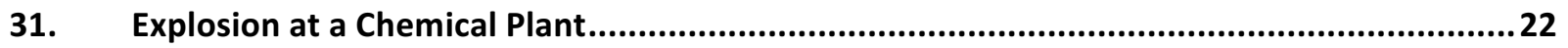

32. Explosion at a Chemical Plant - Future Technology Scenario ........................................23

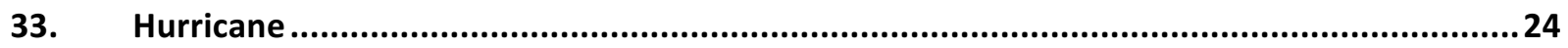

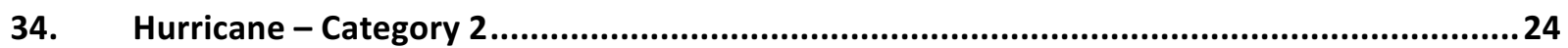




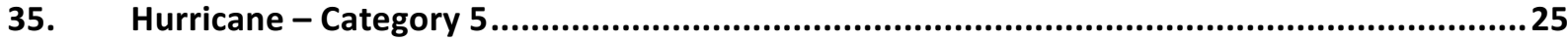

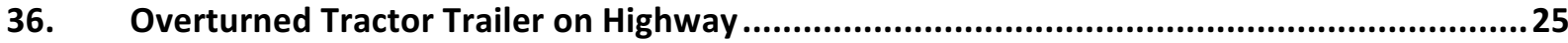

37. Personal Injury Collision with Hazards - Future Technology Scenario ...............................26

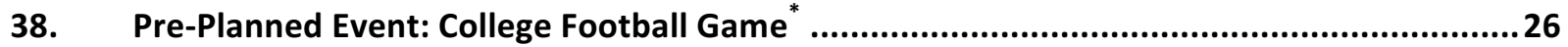

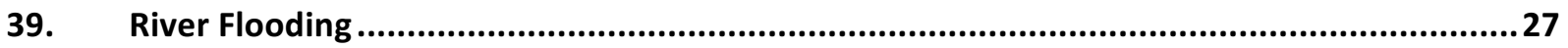

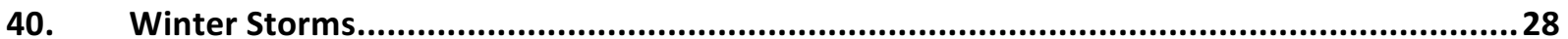

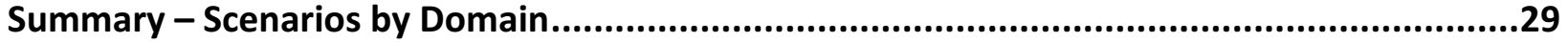

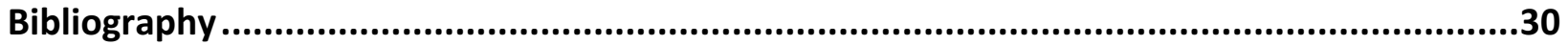

\section{List of Tables}

Table 1. Summary Scenarios by Domain. 


\section{Revision Record}

\begin{tabular}{|l|l|c|}
\hline \multicolumn{1}{|c|}{$\begin{array}{c}\text { Version } \\
\text { Number }\end{array}$} & \multicolumn{1}{|c|}{ Revision Description } & Date \\
\hline 1.0 & $\begin{array}{l}\text { Total of } 40 \text { incident scenarios were compiled with } \\
\text { consistent attributes. }\end{array}$ & June 08, 2017 \\
\hline & \multicolumn{1}{|c|}{} \\
\hline
\end{tabular}




\section{Introduction and Scope}

A project goal for the Public Safety Communications Research (PSCR) Usability Team is to develop use cases for testing and evaluation of new and emerging public safety communications technologies. Toward this end, it is imperative to understand the context of use $^{1}$. The context of use of public safety systems must be considered at the forefront of technological development. Incident scenarios provide a description of an environment in which public safety systems are designed to operate. The scenarios help frame the context of use to better understand first responders' tasks, ensuring that the design of a system will meet the needs of users once the system is implemented in a real-world environment. This document is a collection of public safety incident scenarios collected from fire, EMS and law enforcement domains. Because this collection helps illustrate the context of use and understand user tasks, it should prove helpful for designers, developers and researchers of public safety communications technologies.

The scenarios in this document were compiled from various sources (a mixture of generated and historical scenarios) in the public safety community, including the Department of Homeland Security SAFECOM program [1], the National Institute of Standards and Technology (NIST) Public Safety Communications Research (PSCR) program [2], and a NIST PSCR Security Team workshop report [3] $]^{2}$. Additional scenarios were compiled based on publicly available After Action Reports (AARs) of real-world public safety incidents from the last twenty years, focusing primarily on incidents within the past ten years [see Bibliography 4-26]. The selection of AARs includes a wide variety of incidents from fire, emergency medical services (EMS), and law enforcement. The AARs also cover urban, suburban, and rural regions across the United States (U.S.).

While this collection of scenarios does not cover all possible activities and situations, they represent a variety of realistic incidents, activities, and responses that involve public safety agencies and personnel. This collection is intended to be a living document, and will be updated as new incident reports become available.

\section{About the Scenarios}

In reviewing these numerous scenarios, we found common attributes that would be useful for future use case development for testing and evaluation of public safety communications technologies. The attributes included in each scenario are those that would be important to a

\footnotetext{
1 For a detailed discussion on the context of use, see the Usability Handbook for Public Safety Communications, https://www.nist.gov/ctl/pscr/newsroom/publications/usability-handbook-for-public-safety-communications

${ }^{2}$ Scenarios from sources [1], [2], and [3] were copied as-is from original sources.
} 
first responder in completing their incident response tasks. Therefore, where such attributes are available, they are taken directly from their original source, such as:

- Vignette

- Region and Location

- Time, day and month of the year

- Incident duration

- Actors

- Resources

- Complicating factors or considerations as the incident unfolds

- Incident outcomes

Each scenario starts with key information ${ }^{3}$ about the environment where and when the incident took place:

- Region - for example, Midwest, New England

- Location - Metropolitan city, Urban, Suburban, Rural

- Time of year - for example, weekday, January, hurricane season

We define "Region" using the U.S. Census Bureau's designated 4 regions and 9 divisions within those regions [4]. Remaining attributes are integrated into the incident description and considerations that were discovered as the incident unfolded.

The scenarios in this document fall into one of four categories, and are organized as:

- Fire scenarios

- Law enforcement scenarios

- EMS scenarios

- Multi-discipline scenarios

Within these categories, the scenarios are grouped by type of incident, for example, Wildland Urban Interface (WUI) fire, and listed alphabetically. A table at the end of the document shows an aggregate of the scenarios by domain and their corresponding sources.

NOTE: The focus of each source varied; as such, the scenarios differed in overall theme (for example, looking towards future technologies) and levels of detail provided. Some necessary modifications were made to ensure a consistent set of attributes across scenarios. The modifications did not change the main narrative of the original scenario or incident.

\footnotetext{
3 Not all scenarios in the source references contained each attribute. Missing information is labeled with " $n / a$ " (not available). In addition, SI units are not provided as English units are common nomenclature for first responders in North America.
} 


\section{FIRE}

1. Apartment Building Fire*

Region: $n / a$

Location: Metropolitan city

Time of year: $n / a$

At 15:17, a 9-1-1 call from a cab driver indicated that the apartment building on a street in downtown is smoking and appears to be on fire. The dispatcher notified the fire department to send a fire engine and a fire ladder, and to send the battalion chief as the fire's incident commander. The nearest ambulance was alerted by the dispatcher to proceed to the scene. The dispatcher notified a neighboring jurisdiction to also send an engine to the fire.

\section{Considerations:}

- The building had eight apartments on each of three floors.

- The main fire was discovered in a second floor apartment kitchen where an electric range was burning.

- Two adults and two children were trapped in the apartment suffering from smoke inhalation.

- Social media messages were used to post the status of the response.

Source: [1] [2]

\section{Structure Fire - Future Technology Scenario*}

Region: $n / a$

Location: $n / a$

Time of year: $n / a$

During a response to a building fire, a firefighter uses an app on his/her mobile device to navigate through the building as well as provide firefighter location to the fire incident commander.

\section{Considerations:}

- Does the assessment change if the structure is a small house vs. apartment vs. commercial structure?

Source: [3]

\footnotetext{
* Scenarios from sources [1], [2], and [3] were copied as-is from original sources.
} 


\section{Subway Fire}

Region: South: South Atlantic

Location: Metropolitan city

Time of year: Monday in January

At 15:14, an Office of Unified Communications (OUC) operator received a call from a subway supervisor about a debris fire on the tracks near a major subway station.

Additional 9-1-1 calls were received reporting heavy smoke at and near the station. A train stopped after encountering an accumulation of heavy smoke while traveling southbound in a subway tunnel. After stopping, the rear car of the train was about 386 feet from the south end of the subway station platform.

Ten minutes later, the OUC operator received a call for medics at the station because people could barely breathe due to the smoke. OUC dispatched a Rail Station Box Alarm to the subway station.

\section{Considerations:}

- Due to heavy smoke, responders could not see the train in the tunnel until they were right next to it.

- Radio communication was sporadic in the subway stations and tunnels.

- The side door of the train required special keys and would not open for passengers.

- One person on the train was found unconscious.

- The following were dispatched: 5 Engine Companies; 2 Ladder Trucks; 2 Battalion Fire Chiefs; 1 Battalion Fire Chief to Operations Command Center; 1 Heavy Rescue Squad; 1 Basic Life Support Unit; 1 Advanced Life Support Unit; and 1 Emergency Medical Services Supervisor.

- Passengers and pedestrians near the subway station were evacuated. Rescue personnel estimate that the evacuation was completed by 16:25.

Source: [5]

\section{WUI Fire}

Region: $n / a$

Location: $n / a$

Time of year: $n / a$

A wildfire is steadily approaching a residential neighborhood of about two hundred family homes. Firefighters are working to contain the fire, but the decision is made to evacuate the adjacent neighborhood.

\footnotetext{
* Scenarios from sources [1], [2], and [3] were copied as-is from original sources.
} 


\section{Considerations:}

- Residents might more readily evacuate with more information from fire operations.

Source: [3]

\section{WUI Fire - Midwest}

Region: Midwest: East North Central

Location: Rural

Time of year: Tuesday in May

A report was received at 14:45 of a small outdoor fire on the side of a small road. When responders arrived on scene, the fire had grown significantly, requiring multiple responding organizations.

\section{Considerations:}

- Initial weather condition: temperature $82^{\circ} \mathrm{F}$, humidity $26 \%$.

- Initial winds were sustained at $12 \mathrm{mph}$ (miles per hour), gusting to $21 \mathrm{mph}$ out of the South-Southeast.

- Wind direction changed frequently, and in different directions.

- The area includes hundreds of buildings and primary residences.

- Citizens were evacuated.

- Various aircrafts, tractor plows, and heavy dozers were resources used.

- Fire, police, EMS, energy/natural resources, forest service, and highway departments responded.

- Fire burned approximately 7400 acres.

- Fire was finally $100 \%$ contained 2 days later.

Source: [6]

6. WUI Fire - Mountain-West Region

Region: West: Mountain

Location: Rural

Time of year: Thursday in June

In a small town, 9-1-1 calls started coming in with people viewing haze in the air along with the smell of smoke around 11:54. The exact location of the smoke and fire was not initially known because multiple reports came from different locations. This fire eventually spread to a crown fire traveling through the tree tops.

\section{Considerations:}


- The terrain had numerous small draws with upward hilly sloped conditions located in a forested area.

- Weather was reported with winds from the Southwest, visibility 8 miles, air temperature $95^{\circ} \mathrm{F}$ degrees, and $4 \%$ humidity.

- Evacuation area covered 94000 acres, 13000 homes and 38000 people.

- Approximately 100 agencies were involved. Agencies involved varied from initial attack and response to end of event.

- The following resources were dispatched: 76 engines; 16 air tankers; 5 helicopters; 13 tenders; 5 dozers; 3 ambulances.

- The following military resources were engaged in firefighting efforts: 36 engines; 16 air tankers; 6 helicopters; 25 Overhead; 16 tenders; 4 dozers; 1 Military Fuel Point.

- Fire burned 14280 acres.

- Fire was finally $100 \%$ contained 9 days later.

Source: [7]

7. WUI Fire - Pacific

Region: West: Pacific

Location: Suburban

Time of year: Wednesday in September

A 9-1-1 call about an outdoor fire was received in an area with 2700 residents. The fire was first reported at 14:26, and quickly spread to over 100 acres on hilly terrain. Due to changing wind, the fire expanded at a dangerous rate of spread in all directions, consuming approximately 50000 acres over the next 2 days.

\section{Considerations:}

- The area was in a historic 4-year drought, with high heat and low humidity.

- The topography in the burn area ranges from a high of about 3000 feet in the east to a low of about 600 feet along a river in the northwest.

- 7000 structures including residences and buildings were in the area.

- Mandatory evacuation order was issued.

- County Amateur Radio Emergency Service (ARES) was available as a resource.

- 15 engines, 6 dozers, and 2 water tenders were available resources.

- Fire burned 70868 total acres.

- Fire finally $100 \%$ contained 22 days later.

Source: [8] 


\section{WUI Fire - South-West Region}

Region: West: Pacific

Location: Metropolitan city

Time of year: Tuesday in May

At 10:44, a survey crew using a backhoe ignited a grass fire on the border of the city and its neighboring town. At approximately 10:46, the town's dispatchers began receiving calls of a vegetation fire near a high school, which was on the border of the city and the town. Subsequently, the city's communications center received calls from addresses within the city. It was initially unclear as to the fire's precise point-of-origin, so both the city and the town responded to the incident, with the state also becoming involved. An additional 11 fires occurred in the county over the next few days.

\section{Considerations:}

- The weather was warm with low relative humidity, and increased wind speeds.

- The town, city, and state had to find a common channel and radio system in order to communicate among them.

- Various notification tools were used to alert and evacuate citizens such as: mass notification, door-to-door, social media, 2-1-1, and county website.

- Fire burned 1548 total acres with $84 \%$ of the acreage in the city.

- Fire was finally $100 \%$ contained 4 days later.

Source: [9]

\section{WUI Fire - South-West Region, Multi-City}

Region: West: Pacific

Location: Urban

Time of year: Tuesday in May

During a historical state drought, a report of a fire was called into dispatch at 11:00. As this wildfire was called in, others sparked throughout the county. Personnel from local, state, and federal agencies responded. In addition, military also responded due to a local memorandum of understanding to expedite the use of military aircraft during disasters. The fire peaked on Day 3 with 14 separate fires burning in urban, suburban, and unincorporated communities.

\section{Considerations:}

- Governor declared State of Emergency for county.

- 121000 residences and a military base were evacuated.

- 5 shelters and 6 temporary evacuation centers were available throughout the county. 
- 16 fire engines and 13 water tenders were dispatched from within the county.

- The following military, state, and federal resources were engaged in firefighting efforts: 4 Air Attack Command and Control aircraft; 8 fixed wing Airtankers; 2 United States Forest Service Lead Planes; 13 civilian helicopters; 30 military helicopters (Navy and Marine Corps).

- Fire burned 6000 total acres.

- Fire was finally $100 \%$ contained 9 days later.

Source: [10]

10. WUI Fire - U.S./Mexico Border

Region: West: Pacific, near U.S.-Mexico border

Location: Rural

Time of year: Sunday in June

At 11:00, a fire began near a small town. Initial fire was about 50 acres and posed an immediate structure threat to 4 homes. The fire grew and spread quickly to neighboring jurisdictions.

\section{Considerations:}

- Temperatures reached 107 degrees with 9 percent humidity and winds up to 24 $\mathrm{mph}$.

- The town's population was 656 .

- Cell phone service was affected in the area.

- Power lines were impacted.

- Various notification tools were used to alert citizens such as: social media, 2-1-1, county emergency mobile application and county websites.

- 10 total alert campaigns on evacuation were issued throughout the duration of the incident, with approximately 3983 individuals in the evacuated area.

- The following were dispatched:

- from within the county: 13 fire engines; 7 water tenders; 10 staff/command vehicles; 1 GIS (Geographic Information System) trailer;

- from state: 70 engines; 5 air tankers; 1 air attack; 5 water dropping helicopters; 3 water tenders; 2 bulldozers.

- Fire burned 7609 acres.

- Fire was finally $100 \%$ contained 11 days later.

Source: [11] 


\section{Law Enforcement}

\section{Active Shooter - Future Technology Scenario ${ }^{*}$}

Region: $n / a$

Location: $n / a$

Time of year: $n / a$

During an active shooter incident, a person on scene uses an app to send video of the shooter.

\section{Considerations:}

- Does the assessment change if in a school vs. in a mall?

Source: [3]

\section{Active Shooter - Military Base}

Region: South: South Atlantic

Location: Metropolitan city

Time of year: Monday in September

At 08:17, a 9-1-1 call was received in the city's emergency call center reporting gunshots fired, multiple victims, and a description of the shooter. The caller was an employee using a mobile phone from the $4^{\text {th }}$ floor of a building on a gated military base. At the same time, several employees called the internal emergency number rather than dialing 9-1-1.

\section{Considerations:}

- The military base was home to several classified departments and 14000 employees.

- There were several gated entrances to the installation, but many gates were locked with no personnel to allow entrance, in accordance with the installation's emergency protocols.

- The facility was patrolled by its own police personnel and handful of armed Military Police, contract security officers, and its own fire and emergency services.

- The city's police officers were not familiar with the layout of the military base, initially causing confusion and difficulty in determining the incident location.

- The building was comprised of 5 floors, approximately 600000 square feet, housing 3000 employees and contractors, in thousands of cubicles in a dense, complex, maze-like interior.

\footnotetext{
* Scenarios from sources [1], [2], and [3] were copied as-is from original sources.
} 
- The building housed classified work and required most employees to store mobile phones in lockers in the lobby entrance.

- The building had two large open atriums in the center that rose through all 5 floors.

- The facility had CCTV (closed-circuit television) cameras and video recordings, but were unavailable for an extended period of time.

- An evacuating worker pulled the fire alarm in an effort to alert others in the building.

- Additional shooters were initially suspected. 12 people were shot and killed and several wounded within the first 22 minutes of the incident.

- At least 117 officers from various agencies entered the building during the initial search of the shooter.

- The incident lasted 69 minutes before the threat was neutralized.

Source: [12]

\section{Barricade Standoff}

Region: Northeast: Middle Atlantic

Location: Rural

Time of year: Tuesday in late December

At 19:55, two uniformed officers from the County Sheriff's office went to a home to serve a bench warrant for failure to comply with Felony Drug Court after second felony DWI (driving while impaired). Twelve previous attempts had been made by law enforcement from the County and the State Police to serve the warrant to the male occupant. The wife confirmed his presence and indicated that he had a loaded gun and was not going to cooperate. The Sergeant called for a SWAT (special weapons and tactics) Team.

\section{Considerations:}

- The wife and two children were inside the residence.

- Additional light was required on one side of the residence in order to maintain perimeter security.

- Outdoor temperatures generally ranged between the low 20's to mid-teens and, coupled with at times a 10-15 mph wind, yielded an effective temperature in the low single digits to near zero throughout much of the event. There was snow on the ground.

- The male occupant barricaded himself in the home.

- Occupant said "I am armed up, Come get me" in his final contact with the negotiating team.

- Shots were fired from a second floor window. 
- Resources included mutual aid, robots, tear gas and pepper spray, two APCs (Armored Personnel Carriers), and a helicopter.

- Heavy equipment was used to open-up parts of the home for sending in robots. 4 small robots and 3 larger robots were deployed to serve as eyes and ears of law enforcement, but could not reach all parts of the house.

- The standoff lasted 3 days. Despite continued attempts by negotiators, the male occupant died of a self-inflicted gunshot wound.

Source: [13]

\section{Manhunt on Shooting Suspects}

Region: South: South Atlantic

Location: Metropolitan city

Time of year: Tuesday in June

At $02: 13$, on a routine patrol, a police officer was stopping a car with no rear license plate displayed. The vehicle contained a female driver and a male passenger. When checking for wants, alerts and warrants on the passenger, the officer was notified of an active arrest warrant for worthless checks. At 02:18, a cover car arrived on scene, and a second officer approached the passenger side of the vehicle. When the officers attempted to take the suspect into custody, he immediately fired rounds and struck the officers and fled on foot. The driver fled the scene in the vehicle. At 02:20 Bystanders noticed the unconscious officers and reported the incident to 9-1-1.

\section{Considerations:}

- At 03:30, the K-9 team lost the suspect's scent about 10 blocks away from the crime scene and believed the suspect was picked up in an unknown vehicle. The police helicopter was reporting negative for suspicious heat signatures, confirming the K-9 officers' conclusions.

- The situation changed into a more complex and multi-jurisdictional operation to locate and arrest the suspect who slipped through the perimeter and was now mobile.

- Multiple jurisdictions responded from 22 law enforcement agencies. More than 1000 personnel joined the manhunt.

- The duration of the manhunt was 96 hours and culminated in the arrest of the suspect.

Source: [14] 


\section{Mass Shooting and Bomb Threat}

Region: West: Mountain

Location: Suburb

Time of year: Friday in July

Shortly after midnight, a lone gunman opened fire on moviegoers attending the premiere of a popular movie in a theater complex. The first 9-1-1 call reporting of a shooting came in at 00:38, about 30 minutes into the movie.

At 00:45, the suspect was apprehended by police behind the cinema, next to his car. He was initially mistaken for another police officer because of the tactical clothing he was wearing. When apprehended, the suspect told the police he had booby-trapped his apartment with explosive devices before heading to the movie theater. The suspect's apartment was a three-story residential building in an area surrounded by other multifamily dwellings.

\section{Considerations:}

- There were about 400 people inside the theater room.

- By 01:33, 70 patients were transported to area hospitals. 12 people died from their injuries.

- In addition to those who got shot, at least 12 people are known to have suffered injuries while fleeing the theater.

- The theater was less than a mile from the nearest police station, which was colocated with police headquarters. Because of the proximity, multiple police units were on scene within minutes of the initial calls for help.

- The shooting incident occurred during a police shift change.

- There was little police activity elsewhere in the city and the roads were clear.

- Law enforcement resources available at the shooting site:

- At 00:55, there were 52 police units on scene.

- About 100 law enforcement officers from almost every nearby jurisdiction responded to help. A nearby major city sent a force of 97 officers and supervisors, commanded by a SWAT Lieutenant.

- The FBI soon sent over 100 agents and specialists to assist in the crime scene investigation, questioning of witnesses, and disarming the explosive devices at the apartment.

- Fire and EMS resources responded to the theater shooting:

- Eventually a total of 27 ambulances were on scene.

- Fire apparatus dispatched: 5 paramedic engines; 1 tower truck; 1 fire truck.

- There were at least 1200 people fleeing the theater complex into the surrounding parking lots. The parking lots at the theater complex were congested with people and unattended police vehicles. 
- The traffic in the parking lot and parked police vehicles blocking roads made it difficult to get fire apparatus and ambulances through the maze of vehicles and curbs to get close to the theater and the wounded.

- While a few police units reported their arrival on scene by radio, most did not, in accordance with good radio practice. Some officers were off-duty and drove their personal vehicles.

- Police officers arrived at the bomb threat scene at about 01:30. Most of the initially assigned personnel came from the theater, where the majority of on-duty personnel were still working. Police evacuated five buildings in vicinity.

Source: [15] [16]

\section{Police Ambush}

\section{Region: West: Mountain \\ Location: Metropolitan city \\ Time of year: Sunday in June}

At 11:21, two police officers checked out and went to lunch. A man and his wife entered the restaurant, ambushed and shot both officers. The assailants fled on foot following the shooting, entering a large retail store less than a block away. As they entered they shot into the air then shot and killed a Good Samaritan civilian. They continued to the sporting goods section, where they barricaded themselves and acquired additional ammunition.

\section{Considerations:}

- The assailants took the officers' weapons and ammunition as they left the restaurant.

- At 11:28, an officer entered the rear of the retail store, encountered the assailants, and exchanged gunfire with them. In this exchange, the female assailant was injured. The officer exited the rear of the store to communicate the situation to dispatch.

- Multiple patrol vehicles, SWAT, and EMS responded.

- The retail store had surveillance cameras.

- At 11:49, 2 officers exchanged gunfire with the male assailant and shot and killed him.

- At 11:50, the female assailant shot herself in the head. She was transported to a hospital, where she was pronounced dead.

Source: [17] 


\section{Rioting*}

Region: $n / a$

Location: Urban

Time of year: $n / a$

Police struggled to contain a riot downtown that sparked looting and multiple structure and vehicle fires. Emergency medical technicians (EMTs) were deployed to aid injured citizens and potentially injured public safety actors.

\section{Considerations:}

- Does the assessment change when an injured Law Enforcement Officer (LEO) is the patient?

- Does the assessment change when helpful information about ongoing and anticipated incidents can be crowd sourced?

Source: [3]

\section{Search in a National Park}

Region: Northeast: Middle Atlantic

Location: Rural - national park

Time of year: Weekday

After firing on police, an armed and violent fugitive took refuge in a national park. The park, located about $48 \mathrm{~km}$ (approx. 30 miles) north of a major city, is about $72.8 \mathrm{~km}^{2}$ (approx. 28 square miles) in area. It is heavily wooded and crisscrossed with biking/hiking trails.

\section{Considerations:}

- What changes if the search was for a missing person rather than a fugitive?

Source: [3]

\section{Shooting}

Region: West: Pacific

Location: Suburban

Time of year: Friday in June

At 11:40, a gunman killed his father and brother in their home and set their house on fire. He left the residence and shot a passerby just outside the house. Then, he carjacked

\footnotetext{
* Scenarios from sources [1], [2], and [3] were copied as-is from original sources.
} 
a passing motorist and forced her at gunpoint to drive him across town to a local college. Along the way, he fired at pedestrians, a municipal city bus filled with passengers and a sports utility vehicle on the campus fatally wounding the 2 riders. On campus, he shot and killed a woman and then entered the library firing at a group of library employees who were barricaded in a storage room.

\section{Considerations:}

- The President of the U.S. was in town, attending an event at a private residence.

- Residents in the suburb sheltered in place.

- The School District was on lockdown status in their classrooms and college students hid in rooms throughout campus for hours.

- Hundreds of first responders responded to the event, including local police, campus police, police from neighboring towns, and police from the nearby metropolitan city.

- Tactical EMS responded.

- The gunman was killed in the library during a confrontation with police.

- 13 minutes passed from the time the gunman killed his father and brother to the time he was killed, resulting in 6 deaths and thousands of people evacuated.

- Police and the fire department search for additional gunman on campus for 8 hours.

Source: [18]

\section{Terrorist Car Bomb*}

Region: $n / a$

Location: Urban

Time of year: Weekday

Just as afternoon rush hour was picking up, dispatch received a call of an explosion. The explosion destroyed several cars in the immediate vicinity, blew out the glass doors of a bank building, and started fires in the bank lobby. Law enforcement officers established a perimeter and evacuated nearby buildings.

\section{Considerations:}

- Law enforcement (including state troopers and bomb squad), Fire, and EMS responded to the incident.

- Because of the proximity to a nearby police station, many law enforcement officers responded on foot.

- Personnel responded from other local, state, and Federal jurisdictions, including ATF (Bureau of Alcohol, Tobacco, Firearms and Explosives) and FBI (Federal Bureau of Investigation).

\footnotetext{
* Scenarios from sources [1], [2], and [3] were copied as-is from original sources.
} 
- Mass casualties of more than 50 victims were reported in the street and in the entryway to the bank.

- The source of the explosion was determined to be a car bomb.

- An APB (all-points bulletin) on suspected perpetrators was issued and roadblocks were set up.

- Officers identified and apprehended a suspect at airport and obtained warrants for suspected accomplices.

Source: [1]

\section{Traffic stop*}

Region: $n / a$

Location: $n / a$

Time of year: $n / a$

On a traffic stop, an officer uses a mobile app to contact the communications center and check out the vehicle, provide the location, a vehicle description, and run the license plate and driver ID (identification) against local, State, and Federal records.

\section{Considerations:}

- Does the assessment change if:

- Shots are fired;

- The suspect flees after initially stopping; or

- The driver or vehicle returns a "hit" for a warrant, stolen vehicle, or other officer safety issue.

Source: [3]

\section{Traffic Stop - Future Technology Scenario*}

Region: $n / a$

Location: $n / a$

Time of year: $n / a$

While on routine traffic patrol, an officer observed a car that ran through a red light at an intersection. No wants/warrants were associated with the vehicle. The officer approached the pulled-over vehicle and the officer's on-person video camera scanned the driver's face. The driver did not provide documentation, but the facial recognition results showed that the driver did not match the registered owner and had a record with previous drug possession and assault charges. Backup officers arrived and a vehicle

\footnotetext{
* Scenarios from sources [1], [2], and [3] were copied as-is from original sources.
} 
search was conducted after officers noticed marijuana remains in the ashtray. Several bags of a white substance that appeared to be cocaine were found and the driver was placed under arrest.

\section{Considerations:}

- The vehicle dashboard had a video camera and license plate recognition software connected to the DMV (department of motor vehicles).

- A mobile fingerprint scanner was used to take the driver's prints, confirming the results of the facial recognition match from the on-person video camera, and that the driver was not the registered owner of the vehicle.

- A transport unit took the driver to jail.

- Officers took photos and collected evidence. Field tests showed that the drugs were cocaine.

- A tow truck towed the driver's vehicle.

Source: [1] [2]

\section{Undercover Officer - Future Technology Scenario*}

Region: $n / a$

Location: $n / a$

Time of year: $n / a$

As part of a covert operation, an undercover officer used a mobile application on his/her mobile device to provide operation information back to the operation's command center.

\section{Considerations:}

- What if the undercover officer was compromised?

Source: [3]

\footnotetext{
${ }^{*}$ Scenarios from sources [1], [2], and [3] were copied as-is from original sources.
} 


\section{EMS}

\section{EMS-Heart Attack*}

Region: $n / a$

Location: urban

Time of year: Weekday

At 16:19, dispatch received a 9-1-1 call from the relative of a man who returned home from playing tennis and reported having chest pains. At 16:23, paramedics entered the home to find the patient barely conscious on the living room couch. Paramedics performed a preliminary medical assessment and transferred the patient to the ambulance. The cardiologist at the nearest hospital recommended transport to a different hospital for cardiac catheterization.

\section{Considerations:}

- The patient was wearing a medic alert device; the patient had a severe allergy to penicillin.

Source: [2]

\section{Medical Emergency - Future Technology Scenario*}

Region: $n / a$

Location: $n / a$

Time of year: $n / a$

During a medical emergency response, a paramedic used a mobile app to collect a patient's information (name, age, gender, age, etc.), recorded the patient's vital signs (heart rate, blood pressure, temperature, etc.), and looked up medications. In addition, the app forwarded the patient information to the hospital where the patient was taken to.

\section{Considerations:}

- Do the responder and hospital need the same app to share the information?

- How sensitive is information about communicable diseases? Does it matter whether the patient is in public or at home?

Source: [3]

\footnotetext{
* Scenarios from sources [1], [2], and [3] were copied as-is from original sources.
} 


\section{Routine Patient Services and Car Crash Scenario - Future Technology Scenario*}

Region: $n / a$

Location: suburban

Time of year: $n / a$

At 08:40, a call center for in-vehicle safety systems notified county dispatch of an accident 12 miles southwest of a city. The call center was unable to contact the occupants, but informed dispatch that two occupants were involved in a $50 \mathrm{mph}$ headon collision and roll-over; the belted driver remained in the front seat; a thrown passenger was in the back seat. At 08:52, EMS arrived on scene and found a single vehicle crash into a tree, with roll-over.

\section{Considerations:}

- The occupant driving was a male patient, approximately 50 years old, was semicoherently responding to voice, has no visible injuries, and was complaining of chest and shoulder pain. He had a personal medical data medallion with allergy and medication information, and a baseline EKG (electrocardiogram).

- The $2^{\text {nd }}$ occupant was female, approximately 50 years old, with more severe injuries. The female patient was trapped in the back seat with doors pinned by a collapsed roof. She was unresponsive but breathing, with an open head injury and possible skull fracture.

- A helicopter was deployed to the scene to transfer the female patient to a trauma center.

- The paramedic's assessment indicated that the male patient had a heart attack. He is transported by ground to a nearby hospital for cardiac catheterization, bypassing the closest hospital.

- At 09:20, a second ambulance, a volunteer EMT via a private vehicle, police, a wrecker, and a fire department heavy rescue vehicle also responded to the incident.

Source: [1]

\footnotetext{
${ }^{*}$ Scenarios from sources [1], [2], and [3] were copied as-is from original sources.
} 


\section{Multi-discipline}

\section{Bombings at a Planned Event}

Region: Northeast: New England

Location: Metropolitan city

Time of year: Monday in April

During a large marathon spanning multiple jurisdictions, the first of two bombs was detonated downtown near the finish line at 14:49; the second bomb was detonated thirteen seconds later 180 yards up course on the same street. Following the explosions, first responders (police, fire and EMS), medical volunteers from the marathon staff, and numerous spectators and bystanders quickly responded to the critically injured, triaging their injuries and facilitating their transport to area hospitals.

\section{Considerations:}

- Local and state law enforcement worked with the FBI to secure and process the crime scene, respond to increased calls for suspicious activity and suspicious packages, and conduct the investigation.

- It was later determined that explosions were caused by homemade improvised explosive devices (IEDs) hidden in backpacks and placed on the ground level in marathon viewing areas just seconds before they were detonated. The explosions took the lives of three individuals and injured 264 spectators-many critically injured.

- 2 days after the bombings, the President issued an emergency declaration for the incident.

- 3 days after the bombings:

- At 15:20, the FBI released photos of the suspects to the public.

- At 22:28, a police officer was fatally shot as he sat on patrol in his marked police vehicle on a nearby college campus.

- At 23:20, an SUV (sport utility vehicle) was carjacked, ultimately leading to a firefight between the two suspects and responding officers. One suspect was fatally wounded while the other fled the scene in the stolen SUV.

- Thousands of law enforcement officers arrived from the neighboring states, many of whom self-deployed to the area once it became widely known that one of the bombing suspects was at large in the town.

- 4 days after the bombings:

- A 9-1-1 call was received at 18:42 from a resident reporting a sighting of the suspect in a winterized boat parked in his yard. Officers immediately responded to the home and within moments, more than 100 officers had gathered in front of and behind the home. 
- After a nearly two-hour standoff, at 20:41, the suspect emerged from the boat. He was arrested and transported by ambulance under heavy guard to a medical center.

Source: [19]

\section{Earthquake - Magnitude 6.0}

Region: West: Pacific

Location: Suburban

Time of year: Sunday in August

A magnitude 6.0 earthquake struck the area at 03:20. This was the largest earthquake to strike the area since 1989 . The damage from this earthquake was estimated at $\$ 362.4$

million. This earthquake claimed the life of 1 victim and injured nearly 200 people.

\section{Considerations:}

- Several public facilities and critical infrastructure were significantly damaged, resulting in the temporary closure of several county businesses and government services.

- Many of the occupants of the facilities were forced to relocate in order to provide critical county services.

- Overall, the whole community was facing a long-term recovery effort with significant stress on community resources and personnel.

Source: [20]

\section{Earthquake - Magnitude $7.2^{*}$}

Region: $n / a$

Location: Urban

Time of year: Weekday in Summer

At 09:00, an earthquake of magnitude 7.2 hit a central city area. Multiple brush structure fires were ignited due to damaged power lines and ruptured natural gas lines.

\section{Considerations:}

- The impacted county was 2800 square miles with a population of 450000 .

- 4 incorporated cities and 2 airports were in the county.

- A nuclear power plant was located 11 miles from a neighboring city within the county.

\footnotetext{
* Scenarios from sources [1], [2], and [3] were copied as-is from original sources.
} 
- Governor activated the National Guard and requested Federal assistance.

- Radio Amateur Civil Emergency Service (RACES) provided communications support.

- The public safety radio system and communications with all mobile and portable subscriber units remained operational.

Source: [1]

\section{Earthquake Exercise - Magnitude 6.9}

Region: West: Pacific

Location: Metropolitan city

Time of year: Saturday in April

The exercise scenario:

A 6.9 magnitude earthquake occurred with strong shaking throughout the metropolitan and surrounding areas. Many trees were damaged or knocked down, blocking roads and creating major access problems for first responders. Electricity was out in most nearby areas. There were many downed power lines. Sporadic, small natural gas pipeline leaks were a hazard in many areas. Some water and sewer distribution lines were broken, disrupting service in those areas.

\section{Considerations:}

- Landline telephone and internet service were unavailable throughout the surrounding areas.

- Cell phones did not work depending on which wireless providers' cell towers were damaged.

- Local Radio Amateur Civil Emergency Service (RACES) provided communications support.

Source: [21]

\section{Explosion at a Chemical Plant ${ }^{*}$}

Region: $\mathrm{n} / \mathrm{a}$

Location: Suburb

Time of year: Monday in August

Around noon, a large explosion occurred at a chemical plant. It was later determined that the probable cause of the explosion was a bomb. Thus, a secondary explosive device search was initiated.

\section{Considerations:}

\footnotetext{
${ }^{*}$ Scenarios from sources [1], [2], and [3] were copied as-is from original sources.
} 
- There was the potential for hazardous chemical leaks as well as toxic smoke from the burning chemicals.

- $\quad$ EMS, Law Enforcement, and Fire were all on scene.

- Reverse 9-1-1 warning call was sent to instruct people inside the perimeter to find shelter in the area quickly and to close off all outside ventilation.

- There were mass casualties.

Source: [1]

\title{
32. Explosion at a Chemical Plant - Future Technology Scenario*
}

\author{
Region: $n / a$ \\ Location: Suburb \\ Time of year: $n / a$
}

A large explosion occurred at a chemical plant in a suburb. A potential existed for hazardous chemical leaks as well as toxic smoke emissions from the burning chemicals. Multiple employees were severely injured from the initial blast, and part of the plant was on fire. Plant security officers called 9-1-1, triggering a response from police, fire, EMS, and emergency management personnel.

\section{Considerations:}

- A shopping area was near the chemical plant.

- The chemical plant had security cameras and a fenced perimeter with access by a four-digit code.

- Off-duty personnel with Hazardous Materials (HazMat) and Urban Search and Rescue (USaR) training were called in from surrounding jurisdictions.

- The plant had created digital maps of each floor, including sub-ground levels and parking garages.

- Wireless sensors on fire fighter gear detected hazardous chemicals.

- Law enforcement coordinated with the Dept. of Transportation to divert traffic away from the incident.

- Emergency medicine coordinated with utilities to manage power lines knocked down by the explosion and affected gas lines.

- Incident command suspected the explosion was not an accident and detectives were assigned to begin an investigation in coordination with fire investigators.

- After determining that the probable cause of the explosion was a bomb, incident command initiated a secondary device search by the Explosive Ordinance Disposal team.

- Nearby medical facilities could not handle the casualties.

\footnotetext{
${ }^{*}$ Scenarios from sources [1], [2], and [3] were copied as-is from original sources.
} 
- Some responders were using personal devices. Some responders were using the FirstNet network and others were using commercial networks.

Source: [3]

\section{Hurricane*}

Region: $n / a$

Location: $n / a$

Time of year: $n / a$

A hurricane struck several states, causing significant damage and knocking out power for several days.

\section{Considerations:}

- First responders (both on and off duty) coordinated safety checks with community organizations.

Source: [3]

\section{Hurricane - Category 2}

Region: Northeast: Middle Atlantic Location: Metropolitan city and rural Time of year: Monday in October

A category 2 hurricane was forecast to impact a large coastal area. The storm was expected to have a major impact on several surrounding states.

\section{Considerations:}

- On the Friday before the storm, the governor declared a state of emergency.

- A mandatory evacuation order was issued the day before the storm made landfall.

- Area included 375000 residents and 3 hospitals.

- Over 70 shelters were available for evacuees.

- Multiagency response included hundreds of first responders, government officials, National Guard and FEMA (Federal Emergency Management Agency).

- 25000 emergency and essential vehicles were available.

- 800000 people lost power.

- There were 700000 tons of debris from the storm.

Source: [22] [23]

\footnotetext{
${ }^{*}$ Scenarios from sources [1], [2], and [3] were copied as-is from original sources.
} 


\section{Hurricane - Category $5^{*}$}

Region: South: South Atlantic

Location: Metropolitan city and rural

Time of year: Mid-hurricane season

The National Hurricane Center issued a warning that a category 5 hurricane would impact a large urban area, change directions over open water, and make a second landfall further north. The hurricane made landfall near the metropolitan area, bringing heavy wind and rain that caused widespread wind, surge damage, and flooding.

\section{Considerations:}

- Tens of thousands were forced to evacuate their homes.

- Looting was reported to have occurred along empty coastal areas that were evacuated but not storm-ravaged.

- Local and state personnel responded to the area.

- Mutual aid resources were exceeded; the National Guard was available.

- Several key highways were shut down due to flooding, and access to and from the damaged area was problematic.

- Many small communities lost landline communications and official radio communications.

- The storm caused the cellular network to go down.

- As the incident unfolded, local hospitals became full to capacity.

Source: [1]

\section{Overturned Tractor Trailer on Highway}

Region: West: Pacific

Location: Metropolitan city

Time of year: Tuesday in April

At 14:23, 9-1-1 received calls about an overturned tractor trailer on a major highway, blocking all southbound lanes near downtown. The vehicle ended up on its side in the inside lane adjacent to a construction site. Between 16:00 and 17:00, three other traffic collisions occurred nearby in the city. In addition, the city's professional soccer club was scheduled to play a soccer game at 19:00 in their stadium near the highway.

\section{Considerations:}

- The highway had a limited number of exits.

- The soccer game was projected to have 39000 attendees.

\footnotetext{
${ }^{*}$ Scenarios from sources [1], [2], and [3] were copied as-is from original sources.
} 
- The tractor trailer's operator was transported to the city's medical center with nonlife threatening injuries.

- It took multiple attempts and various equipment to right the overturned tractor trailer.

- $\quad$ Fire department personnel left the scene around 15:06.

- Police department activated beacons at the nearby entrance of the highway and initiated traffic control at other intersections.

- $\quad$ The crash site was not cleared and reopened to traffic until 23:37.

Source: [24]

\section{Personal Injury Collision with Hazards - Future Technology Scenario*}

Region: $n / a$

Location: Metropolitan city

Time of year: Weekday

A high-speed collision between a propane tanker and an SUV (sport utility vehicle) occurred on a major highway during rush hour. The tanker was lying on its side blocking three of the four southbound lanes and was leaking propane on the highway. Four other vehicles suffered subsequent accidents as a result of the primary incident.

\section{Considerations:}

- Members of the public could benefit from knowing how to manage the hazardous materials before first responders were able to advise them.

- Reviewing vehicle schematics while en route could help responders prepare for an extrication. The make/model might come from Machine to Machine (M2M) or citizen report.

Source: [3]

\section{Pre-Planned Event: College Football Game*}

Region: $n / a$

Location: Metropolitan city

Time of year: Weekend in November

A major sporting event was planned for an evening in November. The local university was scheduled to play in a football game against its rival team. State Police were scheduled to provide an escort for the rival football team from and to their hotel. On the day of the game before kickoff, several incidents unfolded: a disabled vehicle caused

\footnotetext{
* Scenarios from sources [1], [2], and [3] were copied as-is from original sources.
} 
a traffic jam, forcing the police escort to take an alternate route to the stadium; officers directing traffic noticed flames inside a parked car near the stadium; and rain froze in some areas. During the game, a woman in the stadium reported that her husband was having chest pains, and police watching security video observed a car in the parking lot being broken into. After the game in a parking area, a family informed a traffic detail officer that they were separated from their 12-year-old son.

\section{Considerations:}

- Placement of "No Parking" barrels and other traffic details were coordinated by local PD (police department) and campus PD prior to the game.

- A fire truck was called to respond to the car fire.

- The freezing rain caused vehicle accidents and adjustments to traffic patterns; a salt truck was dispatched.

- EMS inside the stadium responded to the man with chest pains; an ambulance transported him to the hospital.

- The car theft suspect was apprehended and transported to jail.

- The 12-year old boy was found in a different parking lot and reunited with his family.

Source: [1]

\section{River Flooding}

Region: South: West South Central

Location: Suburb

Time of year: May and October

Historic flash and river flooding occurred on two separate occasions within a six-month time period.

The first flooding event started on a Saturday in May and lasted two days affecting a large area of the state. The flash flooding caused a tragic loss of life and extreme property damage. Immediately following the initial flash flooding, another round of severe weather caused additional flash flooding and tornados. This event hampered rescue and recovery efforts.

On a Friday in October, another catastrophic flood event occurred where water caused portions of a major highway to be closed for a second time that year and the closing of a nearby international airport.

\section{Considerations:}

- The May flooding event was noted for its extreme water velocities, analogous to the velocities of Niagara Falls. 
- The October flooding event was noted for the extreme volume of precipitation in such a short period of time.

- For both flooding events, regional and state teams were deployed, and multiple jurisdictions responded, including Department of Public Safety Emergency Management and National Guard.

Source: [25]

\section{Winter Storms}

Region: Northeast: Middle Atlantic

Location: Suburb

Time of year: Friday in February

Two major snowstorms were expected to hit a suburban county. On the day before the first incident, the National Weather Service (NWS) issued a Winter Storm Warning for accumulations of 16 to 24 inches of snowfall. Two days after the first storm ended, the NWS issued another winter storm warning calling for blizzard conditions.

\section{Considerations:}

- Governor issued a State of Emergency for the entire state on the day of the first storm.

- 30 inches of snow fell over two days during the first storm.

- The second snowstorm brought an additional 25 inches of snow to the area.

- There were 2000 power outages over the course of both storms.

- National Guard, State Police, State Highway Administration, and Red Cross responded.

Source: [26] 


\section{Summary - Scenarios by Domain}

Table 1. Summary Scenarios by Domain.

\begin{tabular}{|c|c|c|}
\hline Type & Number of Scenarios & Source \\
\hline \multicolumn{3}{|l|}{ Fire } \\
\hline Structure Fire & 2 & [1] [2] [3] \\
\hline Subway Fire & 1 & {$[5]$} \\
\hline WUI Fire & 7 & [3] [6] [11] [7] [9] [10] [8] \\
\hline Subtotal & 10 & \\
\hline \multicolumn{3}{|l|}{ Law Enforcement } \\
\hline Active Shooter & 4 & [3] [12] [15] [16] [18] \\
\hline Barricade Standoff & 1 & [13] \\
\hline Manhunt on Shooting Suspects & 1 & [14] \\
\hline Police Ambush & 1 & [17] \\
\hline Rioting & 1 & {$[3]$} \\
\hline Search in a National Park & 1 & [3] \\
\hline Terrorist Car Bomb & 1 & [1] \\
\hline Traffic Stop & 2 & [1] [2] [3] \\
\hline Undercover Officer & 1 & [3] \\
\hline Subtotal & 13 & \\
\hline \multicolumn{3}{|l|}{ Ems } \\
\hline Heart Attack & 1 & [2] \\
\hline Medical Emergency & 1 & [3] \\
\hline Routine Patient Services and Car Crash & 1 & [1] \\
\hline Subtotal & 3 & \\
\hline \multicolumn{3}{|l|}{ Multi Discipline } \\
\hline Bombings at a Planned Event & 1 & [19] \\
\hline Earthquake & 2 & [1] [20] \\
\hline Earthquake Exercise & 1 & [21] \\
\hline Explosion at a Chemical Plant & 2 & [1] [3] \\
\hline Hurricane & 3 & [1] [3] [22] [23] \\
\hline Overturned Tractor Trailer on Highway & 1 & {$[24]$} \\
\hline Personal Injury Collision with Hazards & 1 & [3] \\
\hline Pre-Planned Event: College Football Game & 1 & {$[1]$} \\
\hline River Flooding & 1 & {$[25]$} \\
\hline Winter Storms & 1 & {$[26]$} \\
\hline Subtotal & 14 & \\
\hline Grand Total & 40 & \\
\hline
\end{tabular}




\section{Bibliography}

[1] SAFECOM Program, "Public Safety Statement of Requirements for Communications \& Interoperability, Vol 1, v 1.2," DHS, DC, 2006.

[2] Corner Alliance, Inc., "National Institute of Standards and Technology Report: PSCR's Public Safety Broadband Research and Development Roadmap - Beginning the Process," Corner Alliance, Inc., DC, 2014.

[3] M. Ogata, "NISTIR 8135 Identifying and Categorizing Data Types for Public Safety Mobile Applications: Workshop Report," NIST, Gaithersburg, 2016.

[4] United States Census Bureau, "Geographic Terms and Concepts - Census Divisions and Census Regions," 9 February 2015. [Online]. Available: https://www.census.gov/geo/reference/gtc/gtc_census_divreg.html. [Accessed 9 May 2017].

[5] District of Columbia, "Initial District of Columbia Report on the L'Enfant Plaza Metro Station Incident on January 12, 2015," 12 January 2015. [Online]. Available: http://mayor.dc.gov/sites/default/files/dc/sites/mayormb/publication/attachments/HSE MAInitialReportonWMATAIncident.pdf. [Accessed 31 March 2017].

[6] Wisconsin Department of Natural Resources, Wisconsin, "The Germann Road Fire After Action Review Final Report," Mary 2013. [Online]. Available: http://dnr.wi.gov/topic/forestfire/documents/GermannRoad/GermannRoadFireReport.p df. [Accessed 31 March 2017].

[7] El Paso County, Colorado, Sheriff's Office, "Black Forest Fire After Action Report/Improvement Plan," June 2013. [Online]. Available: http://wildfiretoday.com/documents/Black_Forest_Fire_EPSO_AA_Report.pdf. [Accessed 31 March 2017].

[8] CAL FIRE, California, "Butte Fire Incident Information," September 2015. [Online]. Available: http://cdfdata.fire.ca.gov/incidents/incidents_details_info?incident_id=1221. [Accessed 9 May 2017].

[9] City of San Diego, California, "Bernardo Fire May 2014 After Action Report, City of San Diego Response," May 2014. [Online]. Available: http://wildfiretoday.com/documents/bernardoafteraction.pdf. [Accessed 31 March 2017].

[10] County of San Diego, California, "May 2014 San Diego County Wildfires Afte Action Report," May 2014. [Online]. Available: http://www.readysandiego.org/aar/may-2014san-diego-county-wildfires/May-2014-San-Diego-County-Wildfires.pdf. [Accessed 31 March 2017]. 
[11] City of San Diego, California, "June 2016 Border Fire After Action Report," June 2016. [Online]. Available: http://www.readysandiego.org/aar/Border-Fire-June-2016-AAR.pdf. [Accessed 31 March 2017].

[12] Metropolitan Police Department, Washington, D.C., "After Action Report Washington Navy Yard, September 16, 2013," 16 September 2013. [Online]. Available: http://mpdc.dc.gov/sites/default/files/dc/sites/mpdc/publication/attachments/MPD\%20 AAR_Navy\%20Yard_Posting_07-2014.pdf. [Accessed 31 March 2017].

[13] Sheriff, Tompkins County, "After Action Report - 127 Hornbrook Road, Danby, New York," December 2014. [Online]. Available: http://tompkinscountyny.gov/news/sheriff's-officepresents-after-action-report-hornbrook-road-barricading-incident. [Accessed 31 March 2017].

[14] Office of Community Oriented Policing Services, Florida, "Tampa Bay Manhunt AfterAction Report," 29 June 2010. [Online]. Available: https://www.policefoundation.org/wpcontent/uploads/2015/05/Tampa-manhunt-after-action-report.pdf. [Accessed 31 March 2017].

[15] City of Aurora, Colorado, "Aurora Century 16 Theater Shooting After Action Report for the City of Aurora," 20 July 2012. [Online]. Available: https://www.courts.state.co.us/Media/Opinion_Docs/14CV31595\%20After\%20Action\%20 Review\%20Report\%20Redacted.pdf. [Accessed 31 March 2017].

[16] Aurora Fire Department, Colorado, "Century Theater shooting: Aurora Fire Department incident analysis.," 2007 2012. [Online]. Available: https://hazdoc.colorado.edu/handle/10590/3110. [Accessed 04 May 2017].

[17] Office of Community Oriented Policing Services, DOJ, "Las Vegas After-Action Assessment: Lessons Learned from the Las Vegas Metropolitan Police Department's Ambush Incident," 08 June 2014. [Online]. Available: http://ric-zai-inc.com/Publications/cops-w0798pub.pdf. [Accessed 31 March 2017].

[18] City of Santa Monica, California, "City of Santa Monica June 7th, 2013 Shooting Incident," 07 June 2013. [Online]. Available: http://www.smgov.net/uploadedFiles/Departments/OEM/Video_Archive/Santa\%20Moni ca\%20Shooting\%20Experience\%20verFeb\%202014.pdf. [Accessed 31 March 2017].

[19] Boston Bombings AAR Project Team, "After Action Report for the Response to the 2013 Boston Marathon Bombings," 13 April 2013. [Online]. Available: http://www.mass.gov/eopss/docs/mema/after-action-report-for-the-response-to-the2013-boston-marathon-bombings.pdf. [Accessed 31 March 2017].

[20] Napa County, California, "South Napa Earthquake After Action Report," 24 August 2014. [Online]. Available: http://www.countyofnapa.org/WorkArea/DownloadAsset.aspx?id=4294986549. [Accessed 09 May 2017]. 
[21] City of Oakland Fire Department, Emergency Management Services, California, "CORE Citywide Emergency Response Functional Exercise After Action Report," 25 April 2015. [Online]. Available:

http://www2.oaklandnet.com/oakca1/groups/fire/documents/webcontent/oak057391.p df. [Accessed 31 March 2017].

[22] FEMA, "Hurricane Sandy FEMA After-Action Report," October 2012. [Online]. Available: https://www.fema.gov/media-library/assets/documents/33772. [Accessed 31 March 2017].

[23] New York City, New York, "NYC Hurrican Sandy After Action," October 2012. [Online]. Available: http://www.nyc.gov/html/recovery/downloads/pdf/sandy_aar_5.2.13.pdf. [Accessed 31 March 2017].

[24] City of Seattle, Washington, "State Route 99 Overturned Tractor Trailer Incident Preliminary After Action Report," 24 March 2015. [Online]. Available: http://www.seattle.gov/transportation/docs/After-Action-Report-Final.pdf. [Accessed 31 March 2017].

[25] Hays County / San Marcos Joint EOC Operations, Texas, "Hays County 2015 Flooding Events After Action Report," 2015. [Online]. Available: https://www.co.hays.tx.us/Data/Sites/1/pdf/press-releases/2016/hays-county-mayoctober-2015-flooding-aar.pdf. [Accessed 31 March 2017].

[26] Frederick County Division of Emergency Management, Maryland, "February Winter Storms of 2010 After Action Report," February 2010. [Online]. Available: https://frederickcountymd.gov/DocumentCenter/View/15658. [Accessed 31 March 2017]. 